\title{
Traditional Antipyretics from the text of Usada Wariga Dalem as an Ayurveda knowledge
}

\author{
Review Article
}

\section{Ni Wayan Sariani ${ }^{*}$, I Wayan Rasna², I Nengah Martha², Gde Artawan ${ }^{3}$}

1. PG Scholar, 2. Professor, 3. Doctor,

Post-graduate Program, Ganesha University of Education, Singaraja, Indonesia.

\begin{abstract}
Text Usada Wariga Dalem is one of Usada in Bali as a national cultural heritage which contains the knowledge system of traditional Balinese treatment which includes symptoms of disease, names of diseases, medicinal facilities, how to mix, and how to treat. One of the symptoms contained in the text of Usada Wariga Dalem usada is fever. Handling of fever can be done by using medicinal plants as contained in the text of Usada Wariga Dalem. Treatment with medicinal herbs is still one of the options for Balinese people in treating diseases. Traditional medicinal herbs for fever are often used as alternative and complementary medicines. This research examined what included fever in the text of Usada Wariga Dalem, what were the ingredients of fever medicine in the text of Usada Wariga Dalem and how the medicine could be a complementary and alternative medicine for the Balinese people. This research used a descriptive qualitative research method. literature study and ethnography method. The data needed in this study were collected using a library study, observation, and in-depth interviews. The data is sourced from the Usada Wariga Dalem lontar text, which was collected at the Lontar Study Center, Faculty of Cultural Sciences, Udayana University. The traditional medicine for fever contained in the Usada Wariga Dalem text can be used for complementary and alternative medicine. This traditional treatment using medicinal ingredients from processed plants, has been proven to reduce the patient's fever.
\end{abstract}

Key Words: Traditional medicine, Antipyretic, Usada Wariga Dalem, Cultural heritage, Ayurveda, Complementary and Alternative medicine.

\section{Introduction}

In Balinese life, traditional medicine is written in a script called usada. Usada is a traditional Balinese medicinal system that is still alive today, and there are many lontar usada stored as collections in people's homes and almost every pedanda (priest) has a usada in lontar. usada as the science of traditional Balinese medicine originating from the Vedas, namely Ayurveda.

One evidence that the traditional treatment of medicine continues to present, including the many pedanda (priests) and also other Balian (dukun) who are still actively treating the community and the large collection of usada manuscripts that are still practiced in the homes of Balinese people, in government agencies. - government agencies and private agencies. One of the usada manuscripts which contains a medical system that can be used in Balinese society is Usada Wariga Dalem.

Usada Wariga Dalem is included in Ayurvedic knowledge called Aushadha which is related to Health and disease (1). The word Ayurveda means the science

\section{* Corresponding Author:}

Ni Wayan Sariani

PG Scholar,

Post-graduate Program,

Ganesha University of Education,

Singaraja, Indonesia.

Email Id: niwayansariani204@gmail.com of life which comes from the Vedas (2). Usada Wariga Dalem as one of the local wisdoms owned by the Balinese people which is still used today and is related to regional identity. In Ayurveda there is mention of a traditional medicine called Nattuvaidyam. In addition, it is related to medicine, namely Siddha, Ottamooli, Vishavaidyam and Balacikitsa, it is also related to the local wisdom of a nation. (3)

In the text Usada Wariga Dalem uses herbal ingredients to treat fever. In the results of research by Rajanna et al, herbs can be used for immunity (4). In addition to using herbal plants, the Usada Wariga Dalem text also uses other natural contents. In the results of the study, Pandey et al stated that traditional medicines are alternative medicines that use materials derived from plants, minerals, and organic materials. (5). In Ayurvedic knowledge, antipyretic treatment is known as Jwaraghana (6).

The text of Usada Wariga Dalem is a text written on palm leaves using Balinese script and KawiBalinese language. In this study, researchers used the text Usada Wariga Dalem belonging to the Lontar Library, Faculty of Cultural Sciences, Udayana University. Usada Wariga Dalem as described above is a guide text for Balinese traditional medicine. Traditional medicine as stated in the Regulation of the Food and Drug Supervisory Agency in 2019 which is contained in No. 32 of Article 1, which includes all facilities sourced from animals, plants, and minerals, 
including galenic preparations, and that is used by the community according to norm is applicable in society and used from generation to generation (7). Looking at this statement, if it is linked to the text of Usada Wariga Dalem, this text is a traditional Balinese medicine.

The use of traditional medicine is not a competition with modern medicine, but can be used as complementary and alternative medicine. Sometimes some diseases cannot be cured by modern medicine and can be cured with traditional medicine, or traditional medicinal ingredients can be a complementary medicine that can provide comfort to the patient. One of the symptoms of a disease that can be treated with traditional medicinal ingredients contained in Usada Wariga Dalem is fever. In Ayurveda fever is one of the symptoms of Jataravrana (3). Pirexia (Jvara) affects the body (shareera), sense organs (indriya) and mind (manas), which is why fever is considered the most important in Ayurveda among all diseases (8). The fever symptoms described in the Usada Wariga Dalem text are accompanied by medicinal herbs that can be used to treat them, how to prepare them and how to treat them. This kind of treatment has been proven to be able to cure fever, and if the fever is caused by another disease such as infection, this drug can be used as complementary medicine. For example, if a person suffering from fever cannot sleep, by giving body scrub or spraying, the patient can feel comfortable and sleep well. Because of these benefits, the researchers wanted to examine more deeply the handling of fever by using medicinal ingredients in the text of wariga dalem to be introduced to the younger generation so that they can be used in life.

\section{Aim of the study}

This study aimed to describe the symptoms of the disease, especially the fever, which is contained in the Usada Wariga Dalem text in the context of Balinese culture. Furthermore, it was explained about the medicinal ingredients used to handle it, along with how to mix and how to treat it. Besides that, it also describes how traditional medicine is as complementary and alternative medicine.

\section{Materials and Methods}

This study used qualitative descriptive research methods. Besides that, it also used the literature study method and ethnography method, browse some related articles to strengthen the research results. In addition, the ethnographic method is applied in this study related to studied the social life of the Balinese people in using the usada wariga dalem text. The main focus of this research is to describe the text of Usada Wariga Dalem related to texts about antipyretics and potions that can be used to treat them. The data needed in this study were collected using a library study, observation, and in-depth interviews. The data is sourced from the Usada Wariga Dalem lontar text, which was collected at the Lontar Study Center, Faculty of Cultural Sciences, Udayana University. Several informants are considered to have mastered usada (traditional therapy) in general, Usada Wariga Dalem in particular.

In this paper, a literature search is reviewed to obtain information about plants and facilities used in herbal medicine, traditional medicine and also related to Ayurvedic knowledge.

The experts have examined the lontar manuscripts as recorders of important knowledge that contain past civilizations (9).

Wadnerwar et al, reported the results of their research on the pharmacological significance of Ipomoea carnea and its importance for therapeutic (10). Scholar PD researched Croton bonplandianum $L$. (Euphorbiaceae) which can be used in traditional medicine for several types of diseases. The diseases such as jaundice, acute constipation, abdominal pain, dysentery, external wounds, hypercholesterolemia, hypertension, and infectious diseases (11). Gharge et al researched about plants that can be used to treat diabetes without side effects, but the cost is also low (12).

Many experts have conducted research on the use of plants for traditional medicine such as for reducing fever, such as research on the content of garlic, namely several different organosulfur compounds, in addition to amino acids, vitamins, and micronutrients. In addition, garlic has a very strong odor and taste that can inhibit and induce certain P-450 enzymes (13).

In addition to garlic, onion is also a plant that has been proven to reduce fever. A research result proves in his research that onions contain a compound Allylcysteine sulfoxide (Aliin) which can be used as a compress that serves to reduce heat (14).

The antipyretic in the text of Usada Wariga Dalem also uses hibiscus. The results of research on hibiscus flower (H. rosa-sinensis) that the flower can be used as a prophylactic that can be used to prevent fever. It was also mentioned that this plant provides an alternative way to deal with the side effects produced by chemically synthesized pharmaceutical drugs (15).

In the Usada Wariga Dalem text it is also mentioned that the sidaruri plant can be used as a fever reducer. If you look at the results of research on these plants, sidaguri contains active compounds that have an anti-inflammatory effect by non-selectively inhibiting $\operatorname{COX}(16)$.

Other research on traditional medicine for body recognition was also carried out which resulted in the use of traditional medicine in China to treat acquired immunity in deficiency syndrome (AIDS) (17).

Fever-reducing medicine for Balinese people uses herbs that are mixed into drinking medicine called loloh. Research on loloh has been carried out and has shown results that loloh can be used as a medicine for various types of diseases (18).

Other researchers also discuss about medicinal plants used in traditional medicine both in underdeveloped and developing countries in the world and are used until now (19). In addition, medicinal plants can be used to increase immunity (20).

Research on the use of alternative medicine is also carried out by experts such as alternative medicine 
used to relieve pain during exercise with the aim of losing weight, improving health, and of course having positive goals (21). The study discusses alternative medicine also using magical powers (22).

Related to medicinal plants as traditional medicines, Chinese plants have long been proven to be used as traditional medicines, these plants are used and proven to be able to increase human endurance, especially during the COVID-19 pandemic to ward off the outbreak (23)..

Fennel and pule are plants that are used in usada Bali (usada dalem) and scientific studies have the same properties, namely as pain relievers. For plants in usada Bali that do not have appropriate scientific studies, this can be used as an initial idea for scientific testing (24).

\section{Observations and Results}

\section{The Term for Fever according to the Text of Usada Wariga Dalem}

In the Balinese traditional medicine system, the term body condition which showed signs of heat was described in many different terms. To get clearer information regarding fever in the Usada Wariga Dalem text, observations were made. Observations were made on informants who used medicinal plants contained in the Usada Wariga Dalem text and chose photos of plants that matched the text.

In the text of Usada Wariga Dalem such terms were mentioned by several names including panas tis, 'chills (fever)' (9b) this symptom is felt by the patient when the patient feels hot accompanied by chills.

In the following data there was a symptom that was awak panas "hot body/ fever/ pirexia" (9b), in this case the patient only felt the body hot. In data (9b) there was panas marapah "hot exhausted", in this case, the patient feels their body heat is felt high to the inside.. The next symptom was the tan mtu pluh "no sweat" (10a), this also included heat. Grah uyang "Heat restless" in the data (10a), this symptom the patient felt and was restless, could not sleep. In the data (10a), that was uyang ngulasah, buka panggang, 'restless confused like baked', this symptom was already classified as high fever, this was more than the stifling heat and the patient's body feels very hot like burning. Next, there was the so-called panas uyang-ayingan 'confusion heat' (26a).

The mention of the term was related to Balinese culture, namely the habits experienced by the community. From the results of the interview that the symptoms mentioned above were the symptoms felt by the patient. Of the many terms mentioned, different ingredients were used to treat them.

\section{The Use of Traditional Medicine for Antipyretic as Complementary and Alternative for Balinese}

The Balinese have long recognized and used medicinal plants in an effort to overcome health problems. This is evidenced by the many inherited lontar usada, both stored in people's homes and government and private institutions. Knowledge of nutritious medicinal plants is based on experience and skills that have been passed down from generation to generation. From the description of the medicinal ingredients for fever described in the Usada Wariga Dalem text, it is clear that the use of complementary alternative therapies has been used since ancestors and this behavior has received support from the family because of the belief and belief in the community from generation to generation. Regarding traditional medicine, the Indonesian government has regulated in the Decree of the Minister of Health No. 1076/MENKES/SK/VII/2003, namely treatment that is carried out in society from generation to generation by using experience and skills that cannot be separated from the rules or norms in the community. The facilities used are those that come from the contents of the universe, namely animals, plants, mineral substances, galenic preparations or a mixture of all these medicinal ingredients, for treatment based on experience (25). Based on this, Usada Wariga Dalem is one of the official medical texts regulated by the government and is still used to present. One of the treatments contained in it is antipyretic. Complementary and alternative therapies are methods of overcoming diseases that are carried out as support or companion to conventional medical treatment and as an alternative treatment outside conventional medical treatment. The use of traditional antipyretic from the text of Usada Wariga Dalem as complementary and alternative medicines have helped to alleviate the side effects of conventional medicine, as well as provide comfort and reduce worries about health conditions. This can be felt by the community, that some use this traditional medicine as an alternative medicine, that is, before going to a doctor, the first stage is used ointment or scrub from one of the drug mixtures if the fever does not go down, then go to a doctor. From the results of interviews with traditional healers (traditional healers) and the experience of researchers, many patients can recover using these traditional medicines. There are also those who use this traditional medicine as an alternative medicine, namely when visiting a doctor, the doctor gives a fever-reducing medicine and advises him to take it for 4 hours, but before that 4 hours the fever does not want to go down, so the patient is given this traditional medicine. In addition, this traditional medicine also provides a sense of comfort, namely when the patient experiences anxious heat that he cannot sleep, by giving the use of scrub from traditional medicinal ingredients the patient can sleep and feel comfortable and calm. The following is a description of the antipyretic ingredients contained in the Usada Wariga Dalem text equipped with images that match the contents of the text, how to mix and how to use. 
Ni Wayan Sariani et.al., Traditional Antipyretic from The Text of Usada Wariga Dalem as an Ayurveda knowledge

Table 1. Name and symptoms of fever from the text of Usada Wariga Dalem, the medicinal ingredients, how to process them, and how to use

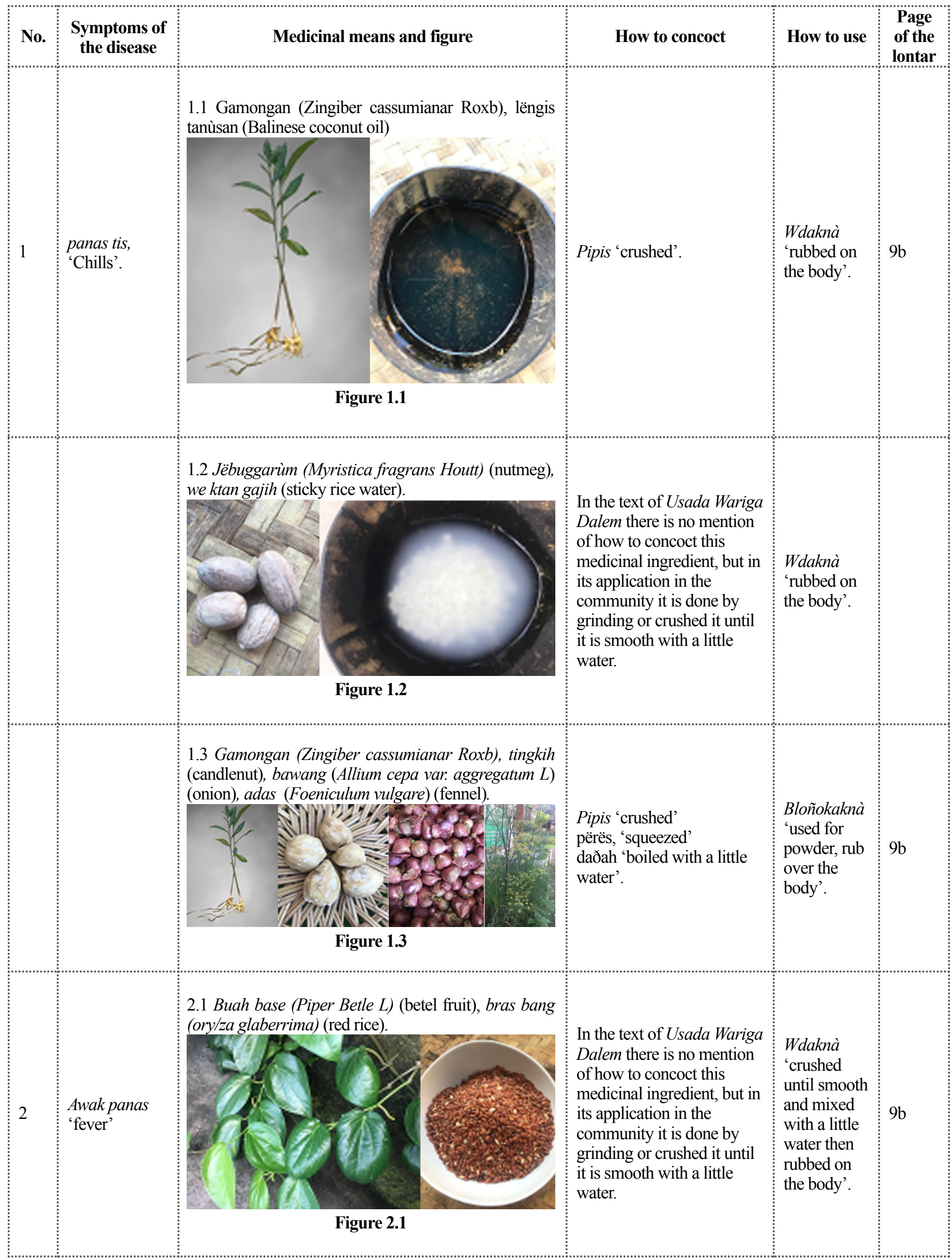


2.2 Rwan dhauśà kling (Gandarusa) (Justicia gendarussa) (gandarusa leaves), trikàtukà (bawang putih (Allium sativum) (garlic), jangu (Acorus calamus L), mesui (Cryptocarya massoy /Oken) Kosterm.), lunak (Tamarindus indica) (sour steamed and dried in the sun).

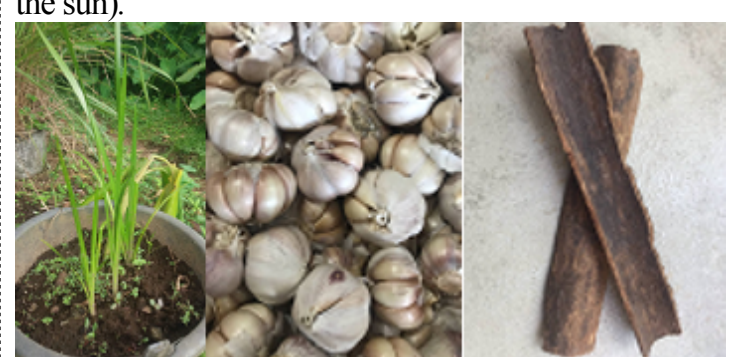

Figure 2.2:Tri ketuka

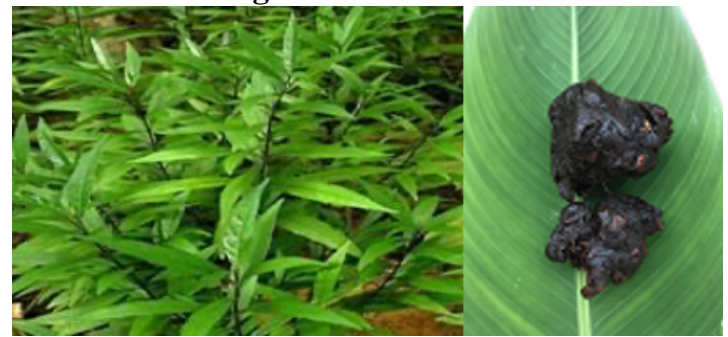

Google search

Figure 2.2: gandarusa leaves, lunak (Tamarindus indica) (sour steamed and dried in the sun).

In the text of Usada Wariga Dalem there is no mention of how to concoct this medicinal ingredient, but in its application in the community it is done by cutting the medicinal ingredients into small pieces and then chewing them

2.3 Rwan pucuk bhang) (Hibiscus rosasinensis) (red hibiscus leaves, dhauśà kling (Gandarusa) (Justicia gendarussa), bañuning sajöng (tuak water).
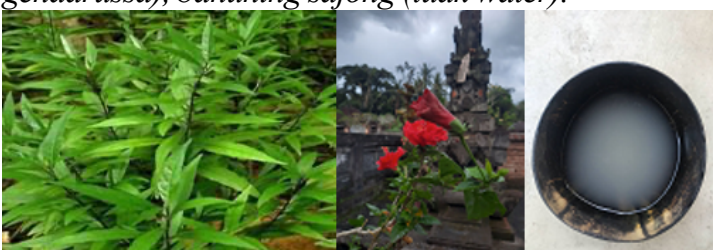

Google search

Figure 2.3

Crushed until smooth and mixed with a little water then rubbed on the body'.

Wdaknà

'rubbed on

the body'.

Pipis dena lëmbat 'crushed

2.4 Rwan kayu puring (Codiaeum variegatum) (kayu puring leaves), bangkët kunir (Curcuma longa) (thick turmeric water), patining lunak (Tamarindus indica) (boiled acid), cuka tahun (vinegar stored for more than one year).

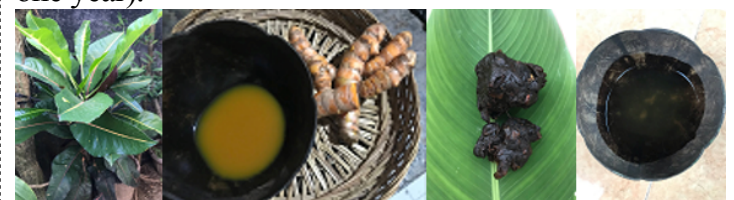
until smooth'

Lepaknà.

'smeared on $25 b$ 







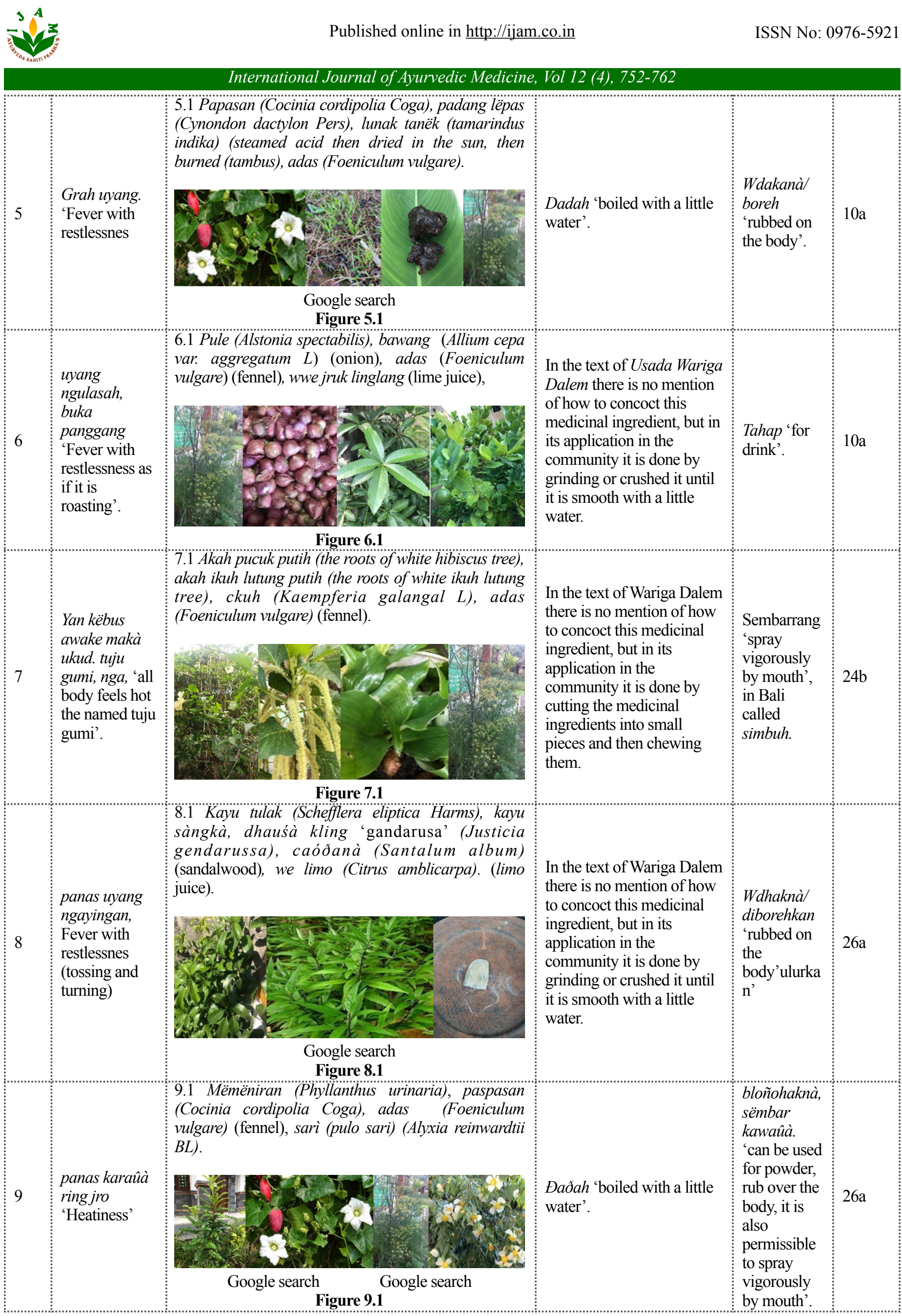




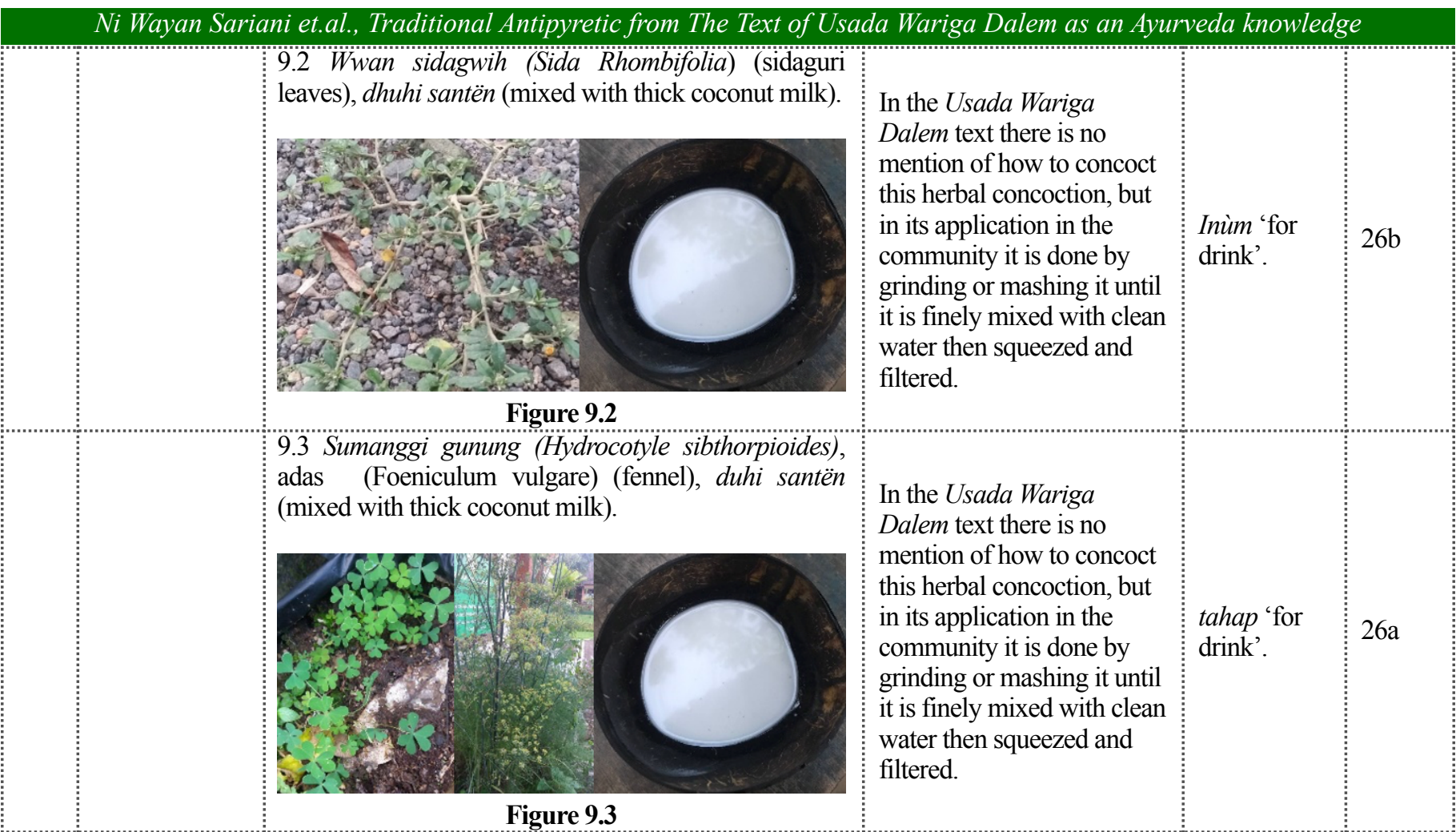

\section{Discussion}

In ancient times, the majority of Balinese people identified fever through the perception of touch. When a person's body temperature was felt to rise, traditional medicine from plants were used, such as sembung leaves, katu leaves, piduh leaves, onion, semanggi, Balinese coconut oil and others as found in the text of Usada Wariga Dalem. The use of traditional medicine was usually used as alternative and complementary medicine. One of the experiences of researchers, when a child had a seizure due to high fever, people panic, and before a rush to the hospital, then a grandmother chewed onions and then sprayed it on the child's forehead, and immediately the child was conscious while continuing to control in hospital.

Fever is not a trivial problem. People could panic if a family member has a fever, especially in children. Many worries arose due to fever such as seizures, steps, or there is a disturbance or there was an emerging disease that was characterized by fever such as infection. Fever can occur due to several etiologies when the temperature set point increases, for example when an infection is the main cause of fever (26).

In modern medicine, fever is measured using a device and then a threshold is determined which is expressed as fever as it is done oleh William F. Wright and Paul G. Auwaerter have done research and had largely established that Which includes normal body temperature is $37.0^{\circ} \mathrm{C}\left(98.6^{\circ} \mathrm{F}\right)$. Mackowiak and his colleagues measured body temperature using an electron thermometer and stated that the normal human body temperature threshold ranges from $36.8{ }^{\circ} \mathrm{C}$ to $37.0^{\circ} \mathrm{C}$, and as an upper threshold for normal body temperature, it is between $37.7{ }^{\circ} \mathrm{C}$. C to $38.0{ }^{\circ} \mathrm{C}(27)$. Determination of the threshold to declare that it is classified as a fever, this is important because in dealing with fever with medication later it is not wrong, this is because of the side effects of pharmaceutical drugs.

In handling fever in Balinese people, detecting fever does not use tools like in modern medicine. According to informants, a traditional healer in Bali, I Made Degung and A.A Gede Agung, he has been practicing traditional medicine for decades, helping patients from house to house and has been proven to cure many diseases. In handling fever, he detects the patient's illness by looking at the signs of the patient's face, eyes, mouth, body hair, nails, and touch. They uses medicinal ingredients found in the usada text, especially in the Usada Wariga Dalem text. They said that the use of fever-reducing drugs in traditional Balinese medicine is not dangerous or has side effects, such as sembung leaves, katu leaves, piduh leaves, onions, shallots, onions, which are processed into drinks that can be used to reduce fever, and these drinks are usually drunk too by people who are healthy for body freshness. Apart from that, shallots, garlic, kencur, candlenut, coconut are used to reduce fever. These ingredients are also used to cook daily meals.

Balinese people have long used traditional medicinal ingredients as first aid to patients, as researchers experienced directly when a child experienced high fever and seizures, a grandmother took an onion and then chewed and sprayed it on the child's forehead and immediately the child realized and immediately taken to the hospital for further treatment. alternative and complementary medicine and still is today. Especially in rural areas, traditional medicine is used as the main treatment, alternative and complementary

In the text of Usada Wariga Dalem contains herbs to treat fever and it is still practiced by Balinese people to present. The use of plants to treat fever patients as traditional medicine is also carried out in 
Thailand, a study identified plants as fever reducers, the use of plants as fever reducers has been entrenched (28)

The traditional medicine of fever in the Usada Wariga Dalem text uses onion and coconut oil. In a study, it was stated that shallots were crushed to release the alliinase enzyme which functions as a catalyst. The reaction would occur in 10-60 seconds. So that this reaction did not occur quickly, then onions, chopped oil can be added, such as the property group allyl sulfide can be dissolved in oil as a non-polar solvent. Oil can function as an insulator because oil could conduct heat well (26)

Onions contain glutamic acid which is a natural essence (natural flavor enhancer), there are also volatile compounds of propyl disulfide and propyl methyl disulfide. If used according to the right dose, red onions can be used as a decrease in body temperature, especially for children aged 1-5 years who experience an increase in body temperature (Jaelani: 2007.p.16) (29)(30)

Antipyretic in the Usada Wariga Dalem text also uses fennel. Fennel extract has antidepressant properties (31). Antipyretic in Usada Wariga Dalem text also uses garlic and onion. The used of garlic and onion for fever contained in the Usada Wariga Dalem text are still used to present and have been proven to be effective as fever reducers. Research from Tantrikulu states that the oil from these two ingredients has a role in changing body fat so that it is good for dealing with fever. Traditional medicinal ingredients are commonly used as food ingredients for health (32).

Research results from C. S. Yang et al. also explained that garlic contains amino acids, vitamins, and micronutrients, besides that garlic has a very strong smell and taste that can be used for health (13) Shallots are plants that are empirically used to reduce fever (antipyretic). Scientifically, onions used in a compress can reduce heat because they contain Allylcysteine sulfoxide compounds (Aliin).86 (14).

Antipyretic in the Usada Wariga Dalem text also uses hibiscus. H. rosa-sinensis hibiscus flower can be used for antipyretic. In addition to the medicine above, there were also uses sidagurii. The active compound Sidaguri has an anti-inflammatory effect by non-selectively inhibiting COX.(16).

The leaves of sembung are also included in the Usada Wariga Dalen text as one of the ingredients for fever-reducing medicine, and this has indeed been commonly used in Balinese society and has been proven to be able to reduce fever. The research of Kusumawati and Yogeswara found that sembung had levels of tannins and antioxidant capacity which were useful for health (33)

The use of traditional medicines to treat diseases is widely used in various countries, not only in developing countries but also in developed countries. One of the 85-year-old tourists who visited Bali when he had a fever did not want to be called by a doctor but only asked for vinegar and said that if the fever did not go down tomorrow, he would call a doctor. This is usually done in his family since he was a child until now, inherited from his grandmother. The use of traditional medicine is also carried out as the following research results.

The processing of traditional medicines contained in the Usada Wariga Dalem text for antipyretics is processed by grinding and then used as a scrub. There are also a process used as a medicine sebur. These two methods of treatment, apart from reducing fever, can also provide comfort to the patient. In addition there are also medicinal ingredients that can be used as drinking drugs and how to process feverlowering drugs like this, namely by mashing and then filtering, in terms of traditional Balinese medicine this is called loloh. Research on loloh made from traditional Balinese medicinal plants was carried out by Wawan Sujarwo et al. In this study, to document the types of traditional Balinese medicinal plants that can be used as loloh, namely traditional Balinese herbs that can be used for health (18). The use of traditional medicinal plants for health has been widely carried out in both undeveloped and developing countries and is still used today (19).

\section{Conclusion}

The knowledge about traditional medicinal ingredients contained in usada is largely unknown to the public, especially the younger generation. Some of the contributing factors are the people's habits that make lontar sacred so that the younger generation does not dare to read it. Another factor is that the knowledge to read lontar is not owned, such as reading Balinese script, and some are not interested in traditional medicine because there is modern medicine from medicine that is easy to obtain and its use is practical.

The text of Usada Wariga Dalem contains the symptoms of the disease, the name of the disease, the medicinal ingredients that can be used to treat it, how to concoct it and how to treat it. One of the symptoms of a disease that could be treated with the medicinal ingredients contained in the text of Usada Wariga Dalem is pyrexia. The results showed that there were 9 different types of names for fever with different symptoms as well as different drugs used to treat it. The ingredients used have been commonly used for food ingredients and traditional medicinal ingredients until now. Several other researchers had also examined medicinal ingredients such as those contained in the Usada Wariga Dalem text, and had proven the benefits of these medicinal ingredients.

In this text, several names that can be paralleled with pyrexia are mentioned, namely panas tis, panas marapah, awak panas, gerah uyang, tan metu peluh, dan panas uyang ngayingan. All the symptoms of the disease had different medicinal ingredients to handle them. Traditional medicine for fever contained in the text of Usada Wariga Dalem can be used for complementary and alternative medicine. This traditional treatment using medicinal ingredients from processed plants, has been proven to reduce the patient's fever. 
Ni Wayan Sariani et.al., Traditional Antipyretic from The Text of Usada Wariga Dalem as an Ayurveda knowledge

\section{Acknowledgement}

We would like to thank the Lontar Study Center, Faculty of Cultural Sciences, Udayana University, the Documentation Center of the Bali Province Cultural Service, and the lontar museum in Gedong Kirtya, Singaraja, Buleleng Regency. Thanks also to the balian usada and health workers: I Made Degung, I Nyoman Sukerta, Ida Bagus Bajra from Pejeng, Ida Bagus Bajra from Payangan, A.A. Gd. Agung, and Ni Nyoman Ariani.

\section{Reference}

1. Gadgil VD. Understanding Ayurveda. 2010;1(1):77-80.

2. Balasubramani SP, Venkatasubramanian P. PlantBased Rasayana Drugs from Ayurveda Plant-Based Rasayana Drugs from Ayurveda. 2011;(May 2014).

3. Chandran S, Dinesh KS, Patgiri BJ, Dharmarajan P. Journal of Ayurveda and Integrative Medicine Unique contributions of Keraleeya Ayurveda in pediatric health care. Journal of Ayurveda and Integrative Medicine. 2018;9(2):136-42.

4. Rajanna M, Bharathi B, Shivakumar BR, Deepak M, Prashanth DS, Prabakaran D, et al. Journal of Ayurveda and Integrative Medicine Immunomodulatory effects of Andrographis paniculata extract in healthy adults e An open-label study. Journal of Ayurveda and Integrative Medicine. 2021;(xxxx).

5. Pandey MM, Rastogi S, Rawat AKS. Indian Traditional Ayurvedic System of Medicine and Nutritional Supplementation. 2013;2013.

6. Chaudhari VM. Role of Medicinal plants in Covid-19 pandemic : An Ayurveda perspective Review Article. 12(2):204-18.

7. BPOM RI. Peraturan Badan Pengawas Obat dan Makanan Nomor 32 Tahun 2019 Tentang Persyaratan Keamanan dan Mutu Obat Tradisional. Badan Pengawas Obat dan Makanan. 2019.

8. Mamidi P. Shukra Dhatugata Jwara - Rabies Encephalitis? International Journal of Complementary \& Alternative Medicine. 2017 May $30 ; 7(2)$.

9. Kesiman MWA, Burie JC, Ogier JM, Grangé P. Knowledge Representation and Phonological Rules for the Automatic Transliteration of Balinese Script on Palm Leaf Manuscript. Computacion y Sistemas. 2017;21(4):739-47.

10. Wadnerwar N, Deogade M. Future perspectives of Therapeutic Claims of an Ethnopharmacological Drug Ipomoea carnea Jacq . - A Critical Review. 12(2):177-84.

11. Scholar PD. Traditional uses, phytochemistry and pharmacology of Croton bonplandianum - A review Review Article Pharmacological reports. 12(2):185-9.

12. Gharge S, Kagawad P, Palled MS, Maste MM, Suryawanshi SS. In-Silico Molecular Docking in Screening of Anti-Diabetic Therapeutics from Medicinal Plants Review Article. 12(2):190-8.
13. Yang CS, Chhabra SK, Hong JY, Smith TJ. Mechanisms of inhibition of chemical toxicity and carcinogenesis by diallyl sulfide (DAS) and related compounds from garlic. In: Journal of Nutrition. 2001.

14. Mahasuari NPS, Trisna NKCA, Karyawati NK, Pawarrangan ABS. UJI HEDONIK PRODUK BOREH PENURUN DEMAM DARI BAWANG MERAH (Allium cepa L.) dan KULIT BATANG PULE (Alstonia scholaris L.). Jurnal Ilmiah Medicamento. 2020;

15. Aziz MA, Raduan S, Zuraini A, Hakim M, Roslida A, Zakaria Z. Anti-Pyretic Activity of two Varieties of Hibiscus Rosa Sinensis L. Biomedical and Pharmacology Journal. 2021;

16. Tanumihadja M, Mattulada IK, Natsir N, Subehan S, Mandey F, Muslimin L. Structural assessment of chemical constituent of sidaguri (Sida rhombifolia linn) and its ability to inhibit cyclooxygenase. Pesquisa Brasileira em Odontopediatria e Clinica Integrada. 2019;19(1):1-7.

17. Liu $\mathrm{Z}$ Bin, Yang JP, $\mathrm{Xu}$ LR. Effectiveness and safety of traditional Chinese medicine in treating acquired immune deficiency syndrome: 2004-2014. Infectious Diseases of Poverty. 2015;4(1):1-6.

18. Sujarwo W, Keim AP, Savo V, Guarrera PM, Caneva G. Ethnobotanical study of Loloh: Traditional herbal drinks from Bali (Indonesia). Journal of Ethnopharmacology. 2015;169:34-48.

19. Sholikhah EN. Indonesian medicinal plants as sources of secondary metabolites for pharmaceutical industry. Journal of thee Medical Sciences (Berkala Ilmu Kedokteran). 2016;48(04):226-39.

20. Xiao C, Guan Q, Tan Y, Hou L, Xie W. Medical plants and immunological regulation. Journal of Immunology Research. 2018;2018.

21. Kim SN, Kim B, Kim J. The Use of Complementary and Alternative Medicine among Korean Young Adult Members of Fitness Centers. Evidence-based Complementary and Alternative Medicine. 2019;2019.

22. Damayanti OV, Seno M. Health belief model pada pasien yang berobat ke pengobatan alternatif. Experentia. 2017;6:57-66.

23. Shahrajabian MH, Sun W, Shen H, Cheng Q. Chinese herbal medicine for SARS and SARSCoV-2 treatment and prevention, encouraging using herbal medicine for COVID-19 outbreak. Acta Agriculturae Scandinavica Section B: Soil and Plant Science. 2020;70(5):437-43.

24. Warditiani NK, Leliqia NPE, Dewi NKIP, Suyadnya IMKA, Citradewi NWW, Megayanti $K$, et al. Penggunaan Adas Dan Pule Sebagai Penghilang Rasa Sakit Dalam Usadha Bali (Usadha Dalem). Jurnal Farmasi Udayana. 2018;6(2):9.

25. Kementrian Kesehatan Republik Indonesia. Kepmenkes Nomor 1076/Menkes/SK/VII/2003 Tentang Penyelenggaraan Pengobatan Tradisional. In: Kementrian Kesehatan Republik Indonesia. 2003. 
26. Riyady PR. The effect of onion ( Allium Ascalonicum L) compres toward body temperature of children with hipertermia in bougenville room. School of Nursing University of Jember. 2016; 253-6.

27. Wright WF, Auwaerter PG. Fever and fever of unknown origin: Review, recent advances, and lingering dogma. Open Forum Infectious Diseases. 2020.

28. Ma L Le, Liu HM, Luo CH, He YN, Wang F, Huang HZ, et al. Fever and Antipyretic Supported by Traditional Chinese Medicine: A Multi-Pathway Regulation. Frontiers in Pharmacology. 2021.

29. Medhyna V, Putri RU. Pengaruh kompres bawang merah terhadap penurunan suhu tubuh bayi saat demam pasca imunisasi di wilayah kerja polindes pagar ayu musi rawas. Maternal Chlid Health Care J. 2020;2(2):107-18.

30. Jaelani. Khasiat Bawang Merah. Journal of Chemical Information and Modeling. 2007.

31. Singh JN, Sunil K, Rana AC. Antidepressant activity of methanolic extract of foeniculum vulgare (fennel) fruits in experimental animal models. Journal of Applied Pharmaceutical Science. 2013;

32. Tanrıkulu CŞ, Tanrikulu Y, Kılınç F, Bahadır B, Can M, Köktürk F. Deneysel korozif özefagus yanıklarında sarımsak yağının (Allium Sativum) yararlı etkileri. Ulusal Travma ve Acil Cerrahi Dergisi. 2017;23(3):181-7.

33. Antioxidant and Antibactrial capacity of Loloh Sembung (Blumea balsamifera) Based on Extraction Methods. Majalah Obat Tradisional. 2016. 